\section{Demência(s), em imagens, narrativas e experiências}

SWINNEN, Aagje \& SCHWEDA, Mark (eds.). Popularizing dementia: public expressions and representations of forgetfulness. Bielefeld, Transcript, 2015 (Aging Studies, n. 6). 410 pp.

\section{Daniela Feriani}

Quais são as implicações teóricas, críticas e éticas da popularização da demência ao longo dos anos? O que o boom de imagens e narrativas tem a nos dizer? Num esforço de pensar a complexidade da demência, tomando-a como um fenômeno cultural que transborda a medicina, o livro Popularizing dementia faz uma análise de mão dupla: pretende compreender, de um lado, como a cultura popular representa a demência e, de outro, como essas imagens afetam, são adotadas e reformuladas pelo público mais geral. Se o cinema, a literatura e a mídia reforçam estereótipos negativos, eles também são potenciais modelos alternativos para pensar e lidar com a demência.

A diversidade de significados e práticas do tema traz múltiplas possibilidades de abordagens teóricas e metodológicas, materiais e campos num diálogo profícuo entre diferentes áreas do conhecimento, como antropologia, filosofia, literatura, arte, cinema, línguas, mídia, gerontologia, enfermagem, educação. ${ }^{1}$ Os autores mostram como a demência vai além de componentes orgânicos, tendo dimensóes sociais, econômicas, políticas, pessoais, numa tentativa de trazer à tona, na medida do possível, as experiências e vozes das pessoas com demência, com implicaçóes importantes para as noções de doença, narrativa, memória e identidade. Ao problematizar o discurso biomédico de "dissolução" e perdas, a coletânea traz outras interpretaçóes possíveis para uma doença que se revela como enigma e emaranhado de relaçóes.

O livro é dividido em três partes. A primeira parte - "Literary fiction" - traz representaçóes da demência em textos literários contemporâneos, discutindo como a estrutura narrativa informa os sentidos da demência e daqueles que a sofrem.

Em "The locus of our dis-ease", Lucy Burke faz uma leitura minuciosa do romance de Margaret Forster, Have the men had enough? (1989), e mostra a relação entre a chamada "época do Alzheimer", na qual há a biomedicalização da doença, e o neoliberalismo, discutindo as reconfiguraçóes das noçóes de família, cuidado e autonomia. Ao contar os dilemas pelos quais uma mulher passa ao se dividir entre as escolhas pessoais e o cuidado da avó com demência, o romance mostra como a família deixa de ser o lócus tradicional do cuidado para ser um campo de conflitos, num contexto de crescente profissionalização do cuidador e da interferência cada vez maior de valores neoliberais, como a linguagem de mercado (bônus $\times$ ônus) e a valorização do indivíduo, nas relações afetivas.

Com um argumento semelhante, de que a demência é uma doença da vida contemporânea, Sadie Wearing, em "Desconstructing the American family", analisa dois livros de ficção - The corrections (2001), de Jonathan Franzen, e May we be forgiven (2013), de A. M. Homes -, mostrando como a demência reconfigura o cuidado e o parentesco ao questionar a família nuclear e paradigmas de subjetividade e saúde, além da crítica aos valores neoliberais. Para além dos diferentes retratos das figuras parentais com demência - mais positiva em Franzen, mais fatalista em Homes - e de diferentes estruturas narrativas - em primeira pessoa $\mathrm{e}$ em terceira pessoa, respectivamente -, os romances exploram os impactos subjetivos da demência e a rede de vulnerabilidades e responsabilidades que ela engendra, numa clara demonstração, segundo Wearing, de como a literatura pode iluminar questóes filosóficas e práticas envolvidas nas relaçóes entre aqueles que convivem com a doença.

A influência de um discurso religioso apocalíptico e de metáforas góticas na representação da demência como o mal é o tema de Marlene Goldman em "Purging the world of the whore and the horror". Ao analisar três livros de literatura moderna e contemporânea canadense - The double hook (1959), de Sheila Watson, Scar tissue (1993), de Michael Ignatieff, e Soucouyant (2007), de David Chariandy -, a autora discute como as mulheres com demência aparecem como fantasmas, vampiros, zumbis, devendo passar por rituais de purificação e expulsão da comunidade. Além da associação entre gênero, idade e perigo, os romances exploram as relaçóes tensas entre as geraçóes. Ao percorrer as 
metáforas da demência ao longo dos livros - como terror e mal por ferir os princípios neoliberais, sendo vista como falha de controle moral -, Goldman argumenta que o ideal religioso de juventude ganha força com os emergentes discursos biomédicos sobre a perda patológica de memória e a crescente responsabilização do indivíduo pela própria saúde.

Para Irmela Marei Krüger-Fürhoff, em "Narrating the limits of narration", as narrativas da demência podem revelar as possibilidades e os limites da literatura e mudar a noção de pessoa como sujeito autônomo, fornecendo novos modos de narrar. A autora analisa quatro textos - "Losing my mind" (2002), de Thomas DeBaggio, "My father's brain" (2001), de Jonathan Franzen, "The old king in exile" (2011), de Arno Geiger, e "Out of mind" (1984), de J. Bernlef -, mostrando a relação entre narrativas do self e suas condições pós-narrativas. Enquanto os textos autobiográficos fazem um esforço para documentar a sobrevivência de uma narrativa coerente, os textos ficcionais, estando em um lugar seguro, acabam indo além ao explorar as falhas e vulnerabilidades daquele que narra, com sentenças cada vez mais curtas e confusas. $\mathrm{O}$ autobiográfico tem o mérito de amenizar o medo da doença, mas com o risco de idealizá-la e de ser menos convincente para o leitor que queira ter a sensação do que é ter demência. Já os textos ficcionais podem estar apenas transportando uma estrutura narrativa já experimentada na literatura pós-moderna, além de deixar os leitores com o que eles pensam ser perda da memória e falhas da linguagem de uma pessoa com demência. A diferença é tanto textual quanto ontológica.

Reconhecendo o potencial das narrativas ficcionais sobre demência em nos fazer mais conscientes de nossos medos e expectativas, Naomi Kruger, em "The 'terrifying question mark", relata o próprio processo de escrever uma ficção sobre a doença de Alzheimer. A autora discute como a sua representação pode ser um novo tipo de estória ao reimaginar e desestabilizar configuraçóes habituais. Como narrar a partir de dentro da desintegração da consciência? Como representar a perda da linguagem quando ela é a única ferramenta? Como transcrever os sentimentos da demência? Como prevenir que o texto seja tâo caótico que ninguém o queira ler? Ao optar pela primeira pessoa, numa prosa não convencional, inacabada, com lapsos temporais, Kruger pretende fazer os leitores entrarem na consciência da personagem com demência e sentirem a falta de coerência, as falhas, os escorregóes da linguagem e as fragilidades deles próprios - de todos nós, afinal - em fazer as conexóes a partir dos fragmentos que são dados. A aposta é a de que a demência possa ser um estímulo para produzir narrativa e inventividade.

A segunda parte do livro - "Art, artistic approaches, and film” - traz expressões da demência em filmes, museus e design, investigando o potencial terapêutico ou didático de tais abordagens num contexto no qual a demência se revela útil para as artes visuais, com forte apelo dramático.

Vendo na arte uma esperança para novas atitudes em relação à demência, Scott Selberg, em "Dementia on the canvas", analisa as obras de dois artistas com doença de Alzheimer - William Utermohlen e Willem de Kooning -, os quais continuaram a produzir até estágios mais avançados da doença, com trabalhos cada vez mais abstratos. A demência como ameaça à representação torna ainda mais complexa e perigosa a correlação entre obra de arte e personalidade do artista: ora a arte é vista como acesso a uma subjetividade que permanece - e as alteraçóes estilísticas ao longo dos trabalhos continuariam a ser avaliadas pelo valor estético, dentro dos critérios artísticos de qualquer obra -, ora é vista como resultado da perda do self - e aí as mudanças nas obras indicariam as alteraçóes da própria doença. Selberg se pergunta o que está por trás do fazer artístico para ele ser tão recomendado para o tratamento da demência e como a demência, por sua vez, pode se mostrar proveitosa para novas potencialidades artísticas.

Em "Cultural projection of dementia in the Reminiscence Museum", Elena Bendien discute como clichês que relacionam reminiscência na velhice e demência são criados no contexto cultural holandês. Com um olhar crítico diante de práticas como terapia da memória, a autora se preocupa com a expansão de imagens sobre demência, as quais podem ter um efeito negativo nos cuidadores e familiares. Bendien faz pesquisa no Museu da Reminisciência, em Rotterdam, no qual há a reconstrução de várias cenas da vida doméstica dos últimos 150 anos. Ao acompanhar a visita de um 
grupo de idosos com algum tipo de demência em estágio inicial, a autora percebe que algumas evocaçôes forjadas não faziam sentido para algumas pessoas, numa demonstração de que não basta ser antigo para ativar a memória e/ou ter alguma relação com os visitantes do museu.

Oliver R. Hautz analisa o "Opening mind through art”, programa artístico para pessoas com demência desenvolvido em 2009 na Universidade de Midwestern, nos Estados Unidos. O autor tenta apreender como os estudantes que ofereceram as atividades mudaram a visão que tinham sobre demência ao longo do semestre durante o qual o programa foi realizado. Ao interagirem semanalmente com os enfermos através de atividades artísticas e criativas, os estudantes mudaram de percepção e atitude em relação a eles - anteriormente de medo e receio -, vendo-os como pessoas únicas, capazes de expressão apesar das dificuldades trazidas pela doença, e com os quais puderem aprender algo para além do programa artístico.

A materialização da demência no design de roupas é o tema do artigo de Sonja Iltanen, em “'Zip!' Dementia materialized in clothing design”. Ao entrevistar designers, a autora discute como as visóes desses profissionais sobre demência são refletidas nas roupas confeccionadas para as pessoas que têm a doença. Atendendo a demandas de cuidadores - as pessoas com demência não são ouvidas -, os designers acabam reforçando alguns estereótipos negativos. Uma das peças mais destacadas é o macacão com zíper atrás, tido como uma roupa que facilita o cuidado e a higiene, além de restringir o movimento e alguns comportamentos considerados inadequados, como a tentativa do enfermo de tirar a roupa em locais inapropriados e mexer nas partes íntimas. A autora mostra como esse tipo de roupa acaba infantilizando as pessoas que a vestem, numa clara relação com os macacóes usados em bebês.

Em "Challenging representations of dementia in contemporary Western fiction film", Andrea Capstick, John Chatwin e Katherine Ludwin discutem quais as implicaçóes da popularização da demência para a própria definição da doença, notando o reforço do discurso biomédico e de preconceitos, como a perda do status humano e "morte em vida”. O artigo mostra o risco de se generalizar situ- açóes e informaçóes que podem ser falsas e/ou muito específicas para cada pessoa, adotando uma posição crítica sobre o uso de filmes - como Iris (2001), The notebook (2004) e Away from her (2006) - na grade escolar de estudantes da área de saúde ao tomá-los como situaçóes de caso sem ponderar sobre como tais representaçóes podem ser perigosas e atender a interesses específicos, como o próprio efeito dramático do cinema. Os autores sugerem alguns filmes independentes - como Ex memoria (2006) e Bay tree voices (2012) - como alternativa à estigmatização da demência ao trazer a diversidade de experiências das pessoas que a sofrem.

Para Lisa Folkmarson Käll, em "Intercorporeal relations and ethical perception", os filmes Away from her (2006) e $A$ song for Martin (2001) mostram como a subjetividade se constitui de maneira intercorporal através, principalmente, do relacionamento entre as pessoas com demência e seus familiares. Apesar das diferenças, os filmes abordam como o self e a agência das pessoas enfermas estão situados numa malha de relaçôes com outras pessoas e instituiçóes, sendo que sentimentos como raiva e frustração podem ser mais expressóes pessoais em relação às mudanças de vida do que sintomas patológicos. Assim, para a autora, o que os filmes trazem à tona é a transformação da subjetividade daqueles que tem e convivem com a doença muito mais do que o discurso biomédico da perda.

$\mathrm{Na}$ terceira parte do livro - "Media discourses and public understandings" -, os autores abordam as concepçôes da demência na mídia e no público mais geral, mostrando as relaçóes entre discursos médicos e narrativas leigas, além de problematizar alguns desenvolvimentos científicos e tecnológicos.

Em "Dementia in the making", Annette Leibing mostra de que forma um conjunto de técnicas - como mudanças no estilo de vida, regulação dos riscos cardiovasculares e validação de biomarcadores - tem mudado seu valor, de um sinal pós-sintomático usado para o diagnóstico e a pesquisa, em 1990, para o indicador do que a autora chamou de "earliness", num contexto em que a prevenção e o diagnóstico precoce são a maior parte da atual agenda de pesquisas. Leibing discute como essas mudanças aparecem na mídia, refletindo sobre os impactos das mesmas na maneira de entender a doença a partir de 
diferentes abordagens sobre o cérebro e sua relação com o corpo, num movimento em que a demência deixa de ser vista como doença cerebral para se tornar uma condição geral de saúde, o que possibilita uma série de intervençóes no estilo de vida (por exemplo, não fumar e fazer exercício físico) a fim de tornar o cérebro mais saudável.

Como a expectativa pelo diagnóstico precoce muda visóes pessoais e respostas sociais para a doença de Alzheimer é a questão discutida por Yvonne Cuijpers e Harro Van Lente em "The meanings of early diagnostics for Alzheimer's disease in Dutch newspapers". Ao analisar artigos de 1995 a 2010, os autores mostram que diferentes significados sobre o diagnóstico precoce estão relacionados com entendimentos específicos sobre a doença e seu futuro: desde uma ideia de demografia apocalíptica e complexo mistério científico até promessas de progresso tecnológico, passando por significados referentes a saúde, cuidado e velhice. Apesar de os artigos dos jornais trazerem outras interpretações possíveis para além do paradigma biomédico, eles acabam por reforçar preconceitos e imagens negativas sobre a doença, como a "perda do self".

Sanna Inthorn e Julia Inthorn, em "Respect for autonomy?", mostram de que forma revistas populares contribuem para o entendimento público da demência. Apesar de compartilharem da preocupação de um reforço da estigmatização pela mídia, as autoras consideram que as representaçóes da demência em jornais e revistas têm implicaçóes para os dilemas éticos diante das tomadas de decisóes de enfermos e cuidadores no dia a dia. As revistas analisadas -Saga Magazine, Yours e Choice - têm o potencial para descrever modelos de cuidado que apoiam o bem-estar das pessoas com demência, valorizando o relacionamento familiar e a experiência emocional envolvida. Apesar disso, as revistas raramente exploram ideias relacionadas com a autonomia, talvez a mais importante questão ética no cuidado das pessoas com demência segundo as autoras, delegando a tomada de decisóes aos cuidadores e familiares.

Em "Representation of Alzheimer's disease among non-specialists", Marie-Christine Nizzi tenta compreender como a doença de Alzheimer ganha significados específicos em contextos culturais diferentes - Paris/França e Boston/Estados Unidos.
Com diferentes sistemas de saúde e de cuidado, a França tem uma longa história de planos governamentais e campanhas massivas na mídia para informar a população, em contraste com Boston, onde a informação sobre a doença é escassa e descentralizada. Ao entrevistar pessoas leigas, a autora notou que as representaçóes dos franceses são mais ricas e estruturadas, com ênfase nos sintomas; já entre os norte-americanos a ênfase foi nos aspectos emocionais do cuidador. Reconhecendo se tratar de uma pesquisa limitada, Nizzi percebeu que, mais do que o gênero e a idade, o fator com maior influência nas respostas foi ter ou não contato com alguém com a doença: se a "perda da memória" foi a expressão mais mencionada por quem não tem contato, as pessoas que convivem com o enfermo citaram a "perda da independência" (franceses) e a "tristeza" (norte-americanos).

Com a possibilidade real de robôs fazerem o trabalho do cuidado, Ike Kamphof, em "In the company of robots", pergunta como esse desenvolvimento tecnológico reconfigura a identidade pessoal e pública de pessoas com demência. Com foco em notícias divulgadas entre 2008 e 2013 pelos projetos CompanionAble e GiraffPlus, voltados para discussão e realização de robôs para o mercado do cuidado e gerenciamento da velhice, $\mathrm{o}$ artigo mostra a reiteraçấo de estereótipos negativos, de um lado, e o potencial para novas visões sobre a identidade das pessoas com demência que emergem das relaçôes com os robôs, de outro. Numa perspectiva crítica que pretende dissolver dicotomias como a frieza das máquinas versus o calor humano, além de uma revisão dos estudos sobre identidade, o artigo discute as implicaçôes éticas dos robôs ajudantes. Por fim, a autora vê no filme Robot \& Frank (2012) um modelo alternativo ao abordar relaçóes de parceria entre Frank, o idoso com demência, e seu amigo robô, muitas vezes mais "humano" do que alguns familiares.

$\mathrm{O}$ que estamos entendendo quando falamos em demência? Ao mostrar a derrapagem conceitual na qual a demência se esbarra, Elana Commisso, em "The zero-degree of dementia", discute as diferentes perspectivas teóricas - materialista/empírica (neurobiológica) e idealista/sociossimbólica (transcendental, fenomenológica, semiótica) - que estão em jogo. Numa tentativa de unir essas perspectivas, 
a autora discute os trabalhos dos filósofos Catherine Malabou, Adrian Johnston e Slavoj Žižek como aqueles que melhor descrevem a complexidade ontológica da demência como um misto de orgânico e inorgânico, um processo entre sujeito e substância, materialidade e experiência subjetiva.

Demência parece mesmo ser um tema escorregadio. Apesar do cuidado dos autores em reconhecer que se trata de um termo guarda-chuva e do esforço muito bem-vindo em mostrar a diversidade de usos, significados e disputas que o mesmo encobre, algumas derrapagens conceituais - como a correlação entre demência e doença de Alzheimer escapam. O próprio subtítulo do livro, ao justapor demência e esquecimento, não faz juz à riqueza de experiências tão bem trilhadas pelos autores.

Popularizing dementia é um livro urgente. Corajoso e ousado, percorre um caminho tortuoso, ainda por ser desbravado. Traz desafios e reinvenções às ciências sociais ao tomar alguém em processo demencial como interlocutor e mapear uma doença tão misteriosa e plural. Se uma aura nebulosa ronda a demência, que o livro possa ser um sopro para levar as reflexóes acadêmicas aos consultórios médicos, jornais e revistas, às casas das pessoas e instituiçôes voltadas ao cuidado.

\section{Notas}

1 Os editores Mark Schweda (filósofo) e Aagje Swinmen (professora assistente do Centro para Gênero e Diversidade da Universidade de Maastricht) são colaboradores dos chamados aging studies. Seguindo tendências como cultural studies e gender studies, os aging studies surgiram na década de 1990 de maneira interdisciplinar com o objetivo de compreender os aspectos culturais do envelhecimento.

DANIELA FERIANI é doutoranda em antropologia pela Universidade Estadual de Campinas (Unicamp). Estuda a composição de um campo de experiências, disputas e imagens da doença de Alzheimer. E-mail: danielaferiani@yahoo.com.br

DOI: $10.17666 / 329314 / 2017$ 